\title{
ANALISIS TRANSAKSI JUAL BELI ACCOUNT GAME ONLINE MOBILE LEGENDS MENURUT PERSPEKTIF EKONOMI ISLAM (Studi Pada Mobile Legends Community Hero di Palu)
}

\author{
Ermawati Ermawati ${ }^{1}$, Nadiah Rahmani ${ }^{2}$, Nurdin Nurdin ${ }^{3}$, \\ ${ }^{1}$ Jurusan Ekonomi Syariah, Fakultas Ekonomi dan Bisnis Islam, IAIN Palu, \\ 2Jurusan Ekonomi Syariah, Fakultas Ekonomi dan Bisnis Islam, IAIN Palu, \\ ${ }^{3}$ Jurusan Perbankan, Fakultas Ekonomi dan Bisnis Islam, IAIN Palu, email: nnurdin@iainpalu.ac.id
}

ABSTRAK

Penelitian ini bertujuan untuk mengetahui mekanisme transaksi jual beli account game online mobile legends, serta untuk mengetahui perspektif Ekonomi Islam mengenai transaksi jual beli tersebut. Penelitian ini menggunakan metode kualitatif, dengan teknik ppengumpulan data melalui observasi langsung dan wawancara mendalam dengan para pelaku game online dikota Palu. Analisis data dilakukan dengan pendekatan analisis secara mendalam terhadap makna yang disampaikan oleh partisipan yang hasilnya menyajikan secara deskriptif hasil yang diperoleh. Dalam penelitian ini, peneliti mengambil data dari responden yang berasal dari komunitas Mobile Legends Community Hero Palu, yang merupakan penjual dan pembeli account game online Mobile Legends. Berdasarkan hasil penelitian transaksi jual beli account game online Mobile Legends sudah sejalan dengan prinsip jual beli yang terkandung dalam ekonomi Islam meskipun produk yang diperdagangkan berbentuk online. Hal tersebut dilihat dari transaksi yang terjadi berdasarkan suka sama suka, antara penjual dan pembeli. Serta kepemilikan yang jelas, sehingga tidak ada terdapat masalah dikemudian hari.

\section{INFORMASI}

ARTIKEL

Katakunci:

Jual beli, akun game, game online, Mobile Legend, ekonomi

Islam 


\section{Jurnal Ilmu Ekonomi dan Bisnis Islam - JIEBI}

\section{Vol. 3 No. 1 Tahun 2021}

\section{PENDAHULUAN}

Perdagangan atau perniagaan adalah kegiatan tukar menukar barang atau jasa atau keduanya yang berdasarkan kesepakatan bersama bukan pemaksaan. Perdagangan adalah jual beli dengan tujuan untuk mendapatkan keuntungan (laba). Jual beli barang merupakan transaksi paling kuat dalam dunia perniagaan (bisnis) bahkan secara umum adalah bagian terpenting dalam aktivitas usaha. Asal dari jual beli adalah disyariatkan, namun diantara bentuk jual beli ada juga yang diharamkan dan ada juga yang diperselisihkan hukumnya. Oleh sebab itu, menjadi suati kewajiban bagi kita sebagai umat muslim untuk mengenal hal-hal yang menentukan sahnya usaha jual beli tersebut. ${ }^{1}$

Dalam perdagangan secara Islam, dijelaskan bahwa transaksi jual beli ada yang bersifat fisik yaitu dengan menghadirkan benda sebagai objek ketika terjadi transaksi atau tanpa menghadirkan benda tersebut dengan cara memesan dan harus dinyatakan benda tersebut secara konkret, baik diserahkan secara langsung, maupun dikemudian hari sampai batas waktu tertentu. $^{2}$ Dalam Islam transaksi ini disebut dengan salam. Seiring berjalannya waktu, transaksi salam ini sudah sering terjadi, apalagi dengan pesatnya teknologi saat ini membuat transaksi ini jauh lebih mudah.

1 Shalah ash-Shawi dan Abdullah alMushlih, Fikih Ekonomi Islam, cet. V, (Jakarta: Darul Haq, 2015), 87.

2 Husein Shaharah Siddiq dan Muhammad adh-Dharil, Transaksi dan Etika Bisnis Islam, (Jakarta: Visi Insani Publishing, 2005), 14.
Perkembangan teknologi informasi dan komunikasi semakin hari semakin berkembang dengan pesat yang berhasil mempengaruhi hampir seluruh aspek kehidupan masyarakat. Terbukanya jaringan komunikasi yang serba transparan memungkinkan manusia berinteraksi bahkan bertransaksi secara instan ke belahan dunia.

Dimulai tahun 2015, pengguna smartphone di kota Palu sudah sangat pesat. Kebutuhan masyarakat kota Palu terhadap smartphone yang menjadi prioritas saat itu hingga sekarang. Bisa dilihat di tahun 2020, kebutuhan akan penggunaan smartphone meningkat pesat di kota Palu dikarenakan semua kebutuhan bisa dipenuhi dengan sebuah benda kecil yaitu smartphone ${ }^{3}$. Hal ini membuktikan bahwa masyarakat kota Palu sangat bergantung pada teknologi.

Masyarakat mendapatkan berbagai kemudahan dalam penggunaan teknologi salah satunya ialah mendapatkan kemudahan dan kenyamanan dalam melakukan transaksi jual beli. Hanya bermodalkan Smartphone dan kuota internet, masyarakat tidak perlu mengantri atau berkeliling di tempat perbelanjaan untuk mendapatkan sesuatu yang diinginkan.

Selain itu, salah satu manfaat dari teknologi adalah sebagai hiburan seperti menonton, mendengarkan musik, dan juga bermain game. Permainan game yang menggunakan koneksi dikenal dengan game online. Dalam kehidupan sehari hari game online ini diminati

${ }^{3}$ https://m.mediaindonesia.com/humani ora/389057/kemenkominfo-89-penduduk-palugunakan-smartphone, diakses pada tanggal 07 Januari 2021 pukul 22.45 WITA. 
Jurnal Ilmu Ekonomi dan Bisnis Islam - JIEBI

Vol. 3 No. 1 Tahun 2021

diberbagai kalangan, mulai darp pelajar, guru, dokter, artis, bahkan pejabat. Sehingga game online ini tidak hanya dijadikan hiburan semata, namun juga menjadi objek yang diperjualbelikan untuk memperoleh keuntungan yang besar.

Ada beberapa permainan game online yang diminati masyarakat salah satunya ialah Mobile Legend Bang-Bang. Permainan ini dapat dimainkan bersama sama dengan teman team. Yang membuat game ini begitu menarik ialah selain bisa dimainkan secara team, walaupun hero mati permainan belum berakhir.

Penggunaan aplikasi Mobile Legend Bang-Bang di kota Palu sendiri dimulai sejak tahun 2016, dalam kota Palu pengguna game online ini berkisar 750 orang, yang dimana data ini didapatkan penulis berdasarkan jumlah anggota pengguna Mobile Legends Bang Bang yang terdaftar dalam sebuah komunitas. Namun ditahun 2019, diadakan acara Mobile Legends: Bang Bang (MLBB) Carnival ke-9, secara tidak disangka sukses menarik 3000 warga untuk berkumpul di alun alun Kota Palu. ${ }^{4}$

Sisi positif dari game online ini, selain bisa dijadikan hiburan, permainan ini sering juga dijadikan sebagai ladang bisnis, dikarenakan game ini memiliki nilai jual. Biasa yang dijual tidak berbentuk fisik dimana hanya berupa account yang terdiri dari id dan password dari game ini. Account yang dijual

\footnotetext{
${ }^{4}$ EsportsID, MLBB Ceriakan Lagi Kota Palu, Pasca Gempa Tahun Lalu, https://esports.id/mobilelegends/news/2019/12/b181eaa49f592e16c772d cb718cd0f/mlbb-ceriakan-lagi-kota-palu-pascagempa-tahun-lalu, diakses pada tgl 07 Januari 2021 pukul 22.45 WITA.
}

biasanya memiliki kelebihan banyaknya hero, skin, level emblem, dan rank.

\section{TINJAUAN PUSTAKA}

\subsection{Pengertian Jual Beli}

Secara terminologi, terdapat beberapa definisi jual beli yang dikemukakan oleh Ulama Fiqh, sekalipun subtansi dan tujuan masingmasing definisi adalah suatu perjanjian tukar menukar benda atau barang yang mempunyai nilai secara sukarela diantara kedua belah pihak, yang satu menerima benda-benda dan pihak yang lain menerimanya sesuai dengan perjanjian atau ketentuan yang telah ditetapkan syara' dan disepakati. ${ }^{5}$

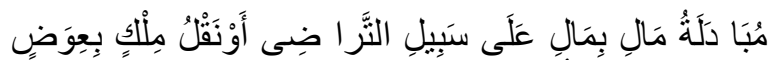

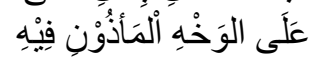

Artinya :

Penukaran benda dengan benda lain dengan jalan saling merelakan atau memindahkan hak milik dengan ada penggantinya dengan cara yang dibolehkan.

Jual beli (البيع) secara bahasa merupakan masdar dari kata (بَاعَ - يَيْيْعُ bermakna memiliki dan membeli. Begitu juga kata شَرَى mengandung dua makna tersebut. Kata aslinya keluar dari kata Karena masing-masing dari dua orang yang melakukan akad meneruskannya untuk mengambil dan

${ }^{5}$ Nursyamsu, Moh. Idham, Ferdiawan, "Pelaksanaan Penimbangan Jual Beli Biji Coklat Dalam Tinjauan Ekonomi Islam : Studi Desa Bulili Kecamatan Nokilakaki Kabupaten Sigi", Jurnal Fakultas Ekonomi dan Bisnis Islam, Institut Agama Islam Negeri Palu, Vol. 2, No. 1, tahun 2020. 
Jurnal Ilmu Ekonomi dan Bisnis Islam - JIEBI

Vol. 3 No. 1 Tahun 2021

memberikan sesuatu. Orang yang melakukan penjualan dan pembelian disebut البََِّّانِ dari kata آَبَاعَ الثَنَيْئ artinya menawarkan jual beli.

Pengertian jual beli secara syara' adalah tukar menukar harta dengan harta lain yang memiliki dan memberikan kepemilikan. Sebagian ulama memberi pengertian: tukar menukar harta meskipun masih ada dalam tanggungan atau kemanfaatan yang mubah dengan sesuatu yang semisal dengan keduanya, untuk memberikan secara tetap. Kedua pengertian tersebut mempunyai kesamaan dan mengandung hal-hal antara lain:

a. Jual beli dilakukan oleh dua orang (dua sisi) yang saling melakukan tukar.

b. Tukar menukar tersebut atas suatu barang atau sesuatu yang dihukumi seperti barang, yakni kemanfaatan dari kedua belah pihak.

c. Sesuatu yang tidak berupa barang atau harta atau tidak dihukumi seperti tidak sah untuk diperjual belikan.

d. Tukar menukar tersebut tetap berlaku, yakni kedua belah pihak memiliki sesuatu yang diserahkan kepadanya dengan adanya ketetapan jual beli dengan kepemilikan yang abadi. ${ }^{6}$

\subsection{Dasar Hukum Jual Beli}

Jual beli merupakan perbuatan kebajikan yang telah disyariatkan dalam Islam, hukumnya boleh. Mengenai transaksi jual beli ini banyak disebut dalam Al-Qur'an, hadist, dan ijma'.

\footnotetext{
${ }^{6}$ As-Sayyid Sabiq, Fiqh as Sunnah , juz -3, (Beirut: Dar al-Fikr, 1983), 126.
}

Ayat-ayat Al-Qur'an dan hadist yang berkenaan dengan transaksi jual beli antara lain:

Q.S An-Nisa/4:29:

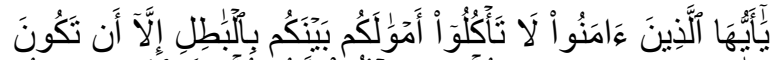

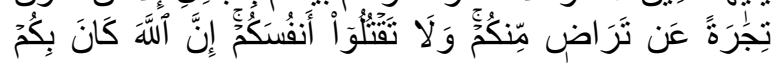

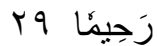

Terjemahnya:

Wahai orang-orang yang beriman janganlah kamu saling memakan harta sesamamu dengan jalan yang batil (tidak benar), kecuali dalam perdagangan yang berlaku atas dasar suka sama suka diantara kamu. Dan janganlah kamu membunuh dirimu. Sungguh, Allah Maha Penyayang kepadamu. ${ }^{7}$

Hai orang-orang yang beriman! Janganlah kamu makan harta sesamamu dengan jalan yang batil) artinya jalan yang haram menurut agama seperti riba dan gasab atau merampas (kecuali dengan jalan) atau terjadi (secara perniagaan) menurut suatu qiraat dengan baris di atas sedangkan maksudnya ialah hendaklah harta tersebut harta perniagaan yang berlaku (dengan suka sama suka diantara kamu) berdasar kerelaan hati masing-masing, maka bolehlah kamu memakannya. (Dan janganlah kamu membunuh dirimu) artinya dengan melakukan halhal yang menyebabkan kecelakaannya bagaimanapun juga cara dan gejalanya baik di dunia dan di akhirat. (Sesungguhnya Allah maha penyayang kepadamu) sehingga dilarang-Nya kamu berbuat demikian. ${ }^{8}$ (Tafsir AlJalalayn)

\footnotetext{
${ }^{7}$ Abu Fathan Al Baihaqi,Al-Fathan, (Jakarta; CV. Al Fatih Berkah Cipta, 2016), 83

8 https://tafsir.com/4-an-nisa/ayat-29, diakses pada tanggal 18 April pukul 21.34 WITA.
}

e-ISSN: 2686-6633 


\section{Jurnal Ilmu Ekonomi dan Bisnis Islam - JIEBI \\ Vol. 3 No. 1 Tahun 2021}

Hubungan ayat tersebut dalam penelitian ini ialah suka rela yang harus ada pada transaksi jual beli dalam bentuk apapun. Sehingga tidak terjadinya perilaku yang merugikan dalam transaksi jual beli khususnya pada akun game online.

Dalam transaksi jual beli, Allah swt memberikan rambu-rambu agar berjalan sesuai dengan prinsip Islam yaitu menghindari perselisihan diantara kedua belah pihak, perbuatan yang dilarang. Diantara ketentuan tersebut yaitu anjuran agar setiap transaksi dalam muamalah dilakukan secara suka sama suka. Rasulullah saw bersabda:

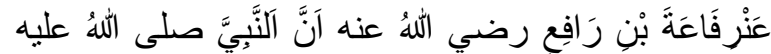

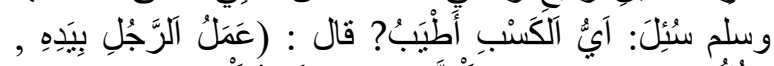

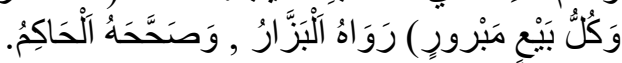

Artinya:

Dari Rafa'ah bin Rafi' r.a. sesungguhnya Nabi saw pernah ditanya seorang sahabat mengenai usaha atau pekerjaan, apakah yang paling baik?Rasul saw menjawab: usaha seorang dengan tangannya sendiri dan setiap jual beli yang baik. ${ }^{9}$

Dari hadist diatas dapat dipahami bahwa al-ba'i (jual beli) adalah perbuatan yang baik. Dalam jual beli seseorang berusaha untuk saling tolongmenolong. Ijma' ulama menyepakati bahwa al-ba'i boleh dilakukan, kesepakatan ulama ini didasari tabiat manusia yang tidak bisa hidup tanpa ada pertolongan dan bantuan dari saudaranya. Tidak ada seorangpun yang

\footnotetext{
${ }^{9}$ Al-Hafidh Imam Ibnu Hajar Al-Asqalany, Bulughul Maram Min Adillatil Ahkaam, Hadist No.800, terj. Dani Hidayat, (Tasikmalaya: Pustaka Al-Hidayat , 2008), 196.
}

memiliki segala barang yang ia butuhkan. ${ }^{10}$

Hadist diatas memiliki keterkaitan dalam penelitian ini. Tidak diketahui apa dorongan para pengguna akun game online ini memutuskan untuk menjual akunnya. Bisa saja hasil dari penjualannya untuk dapat melangsungkan hidup. Begitupun sebaliknya, konsumen memutuskan untuk membeli akun untuk menghibur dirinya, atau mungkin lebih dikembangkan dan dijual dengan harga tinggi. Jadi unsur tolong menolong dalam transksi jual beli akun game online ini masih ada.

\subsection{Ketentuan Transaksi Jual Beli Online}

Ketentuan transaksi jual beli online menurut UU no 19 tahun 2016 sebagai berikut ;

a. Hak Konsumen

1) Hak atas kenyamanan, keamanan, dan keselamatan dalam mengkonsumsi barang dan/atau jasa;

2) Hak untuk memilih barang dan/atau jasa serta mendapatkan barang dan/atau jasa tersebut sesuai dengan nilai tukar dan kondisi serta jaminan yang dijanjikan;

3) Hak atas informasi yang benar, jelas, dan jujur mengenai kondisi dan jaminan barang dan/atau jasa;

4) Hak untuk didengar pendapat dan keluhannya atas barang dan/atau jasa yang digunakan;

5) Hak untuk mendapatkan advokasi, perlindungan dan upaya

\footnotetext{
${ }^{10}$ Amir Syarifuddin, Garis-garis Besar Fiqih, (Bogor: Kencana, 2003), 223.
} 
penyelesaian sengketa perlindungan konsumen secara patut;

6) Hak untuk mendapat pembinaan dan pendidikan konsumen

7) Hak untuk diperlakukan atau dilayani secara benar dan jujur serta tidak diskriminatif;

8) Hak untuk mendapatkan kompensasi, ganti rugi dan/atau penggantian, apabila barang dan/atau jasa yang diterima tidak sesuai dengan perjanjian atau tidak sebagaimana mestinya;

9) Hak-hak yang diatur dalam ketentuan perundang-undangan lainnya. ${ }^{11}$

b. Kewajiban Konsumen

1) Membaca atau mengikuti petunjuk informasi dan prosedur pemakaian atau pemanfaatan barang dan/atau jasa, demi keamanan dan keselamatan;;

2) Beritikad baik dalam melakukan transaksi pembelian barang dan/atau jasa;

3) Membayar sesuai dengan nilai tukar yang disepakati;

4) Mengikuti upaya penyelesaian hukum sengketa perlindungan konsumen secara patut. ${ }^{12}$

c. Hak Pelaku Usaha

1) Hak untuk menerima pembayaran yang sesuai dengan kesepakatan mengenai kondisi dan nilai tukar barang dan/atau jasa yang diperdagangkan;

2) Hak untuk mendapatkan perlindungan hukum dari tindakan konsumen yang beritikad tidak baik.

\footnotetext{
${ }^{11}$ Zulham, Hukum Perlindungan Konsumen,(Jakarta: PT Kharisma Putra Utama, 2013), 50 12 Ibid, 52.
}

3) Hak untuk melakukan pembelaan diri sepatutnya di dalam penyelesaian hukum sengketa konsumen;

4) Hak untuk rehabilitasi nama baik apabila terbukti secara hukum bahwa kerugian konsumen tidak diakibatkan oleh barang dan/atau jasa yang diperdagangkan;

5) Hak-hak yang diatur dalam ketentuan peraturan perundanganundangan lainnya. ${ }^{13}$

d. Kewajiban Pelaku Usaha

1) Beritikad baik dalam melakukan kegiatan usahanya;

2) Memberikan informasi yang benar, jelas dan jujur mengenai kondisi dan jaminan barang dan/atau jasa serta memberi penjelasan penggunaan, perbaikan, dan pemeliharaan;

3) Meperlakukan atau melayani konsumen secara benar dan jujur serta tidak diskriminatif;

4) Menjamin mutu barang dan/atau jasa yang diproduksi dan/atau diperdagangkan berdasarkan ketentuan standar mutu barang dan/atau jasa yang berlaku;

5) Memberi kesempatan kepada konsumen untuk menguji, dan/atau mencoba barang dan/atau jasa tertentu serta memberi jaminan dan/atau garansi atas barang yang dibuat dan/atau diperdagangkan;

6) Memberi kompensasi, ganti rugi dan/atau penggantian atas kerugian akibat penggunaan, pemakaian, dan pemanfaatan barang dan/atau jasa yang diperdagangkan;

7) Memberi kompensasi ganti rugi dan/atau penggantian apabila barang dan/atau jasa yang diterima

13 Ibid, 53. 
Jurnal Ilmu Ekonomi dan Bisnis Islam - JIEBI

Vol. 3 No. 1 Tahun 2021

atau dimanfaatkan tidak sesuai dengan perjanjian. ${ }^{14}$

a. Ketentuan Pembayaran

1) Alat bayar harus diketahui jumlah dan bentuknya, baik berupa uang, barang, atau manfaat;

2) Pembayaran harus dilakukan pada saat kontrak disepakati;

3) Pembayaran tidak boleh dalam bentuk pembebasan hutang.

b. Ketentuan Tentang Barang

1) Harus jelas ciri-cirinya dan dapat diakui sebagai hutang;

2) Harus dapat dijelaskan spesifikasinya;

3) Penyerahannya dilakukan kemudian;

4) Waktu dan tempat penyerahan barang harus ditetapkan berdasarkan kesepakatan;

5) Pembeli tidak boleh menjual barang sebelum menerimanya;

6) Tidak boleh menukar barang, kecuali dengan barang sejenis sesuai dengan kesepakatan;

c. Ketentuan Salam Paralel

1) Penjual harus menyerahkan barang tepat pada waktunya dengan kualitas dan jumlah yang telah disepakati;

2) Jika penjual menyerahkan barang dengan kualitas yang lebih tinggi, penjual tidak boleh meminta tambahan harga;

3) Jika penjual menyerahkan barang dengan kualitas yang lebih rendah, dan pembeli rela menerimanya, maka ia tidak boleh menuntut pengurangan harga (diskon);

4) Penjual dapat menyerahkan barang lebih cepat dari waktu yang disepakati dengan kualitasnya dan jumlah barang sesuai dengan

\footnotetext{
14 Ibid, 56.
}

kesepakatan, dan ia tidak boleh menuntut tambahan harga.

5) Jika semua atau sebagian barang tidak tersedia pada waktu penyerahan, atau kualitasnya lebih rendah dan pembeli tidak rela menerimanya, makan ia memiliki dua pilihan yaitu membatalkan kontrak dan meminta kembali uangnya, atau menunggu sampai barang tersedia.

d. Pembatalan Kontrak : Pada dasarnya pembatalan salam boleh dilakukan, selama tidak merugikan kedua belah pihak

e. Perselisihan : Jika terjadi perselisihan diantara kedua belah pihak, maka persoalannya diselesaikan melalui Badan Arbitrasi Syari'ah setelah tidak tercapai kesepakatan melalui musyawarah. ${ }^{15}$

\subsection{Pengertian Game Online}

Game online merupakan paduan dari kata game dan online yang belakangan membentuk sebuah frasa baru dengan makna tersendiri. ${ }^{16}$ Game merupakan serapan dari Bahasa Inggris yang artinya permainan atau pertandingan. ${ }^{17}$ Sedangkan online dalam bahasa Indonesia istilah online dipadankan menjadi dalam jaringan (daring), yaitu perangkat elektronik

15 Surat Keputusan Fatwa Dewan Syariah Nasional No: 05/DSN-MUI/IV/2000 tentang Jual Beli Salam

16 Tungari, K., Nurdin, N., \& Kusumawati, D. (2016). Analisis Skill dan Ability Karakter pada Game Online Dota2 Esport. Jurnal Elektronik Sistem Informasi dan Komputer, 1(2), 1735.

17 Jhon M.Echols dan Hasan Sadily, Kamus Isnggris Indonesia, (Jakarta: PT Gramedia Utama,2010), 63. 
Jurnal Ilmu Ekonomi dan Bisnis Islam - JIEBI

Vol. 3 No. 1 Tahun 2021

yang terhubung ke jaringan internet. ${ }^{18}$ Jadi Game Online adalah sebuah permainan yang digunakan dalam jaringan internet.

Game online merupakan permainan yang dapat dimainkan oleh multipemain melalui internet. Game online tidak hanya memberikan hiburan tetapi juga memberikan tantangan yang menarik untuk diselesaikan sehingga individu bermain game online tanpa memperhitungkan waktu demi mencapai kepuasan. Hal ini menjadikan gamer tidak hanya menjadi pengguna game online tetapi juga dapat menjadi pecandu game online.

\subsection{Jual Beli Account Game Online Mobile Legends}

Praktek jual beli ini dilakukan menggunakan jaringan internet dengan adanya interaksi antara satu orang dengan lainnya untuk mencapai tujuan tertentu. Ketika seseorang ingin bermain game Mobile Legends ini maka terlebih dahulu membuat akun agar dapat masuk ke permainan tersebut. jika sudah, maka pemain langsung dapat menikmati game tersebut. ${ }^{19}$

Pemain akan mengendalikan satu hero dalam satu pertandingan. Pemain bisa memilih hero tersebut dari daftar hero yang dimiliki. Hero yang ada dapat dikategorikan menjadi beberapa kelompok yaitu marksman, tank, support,

\footnotetext{
${ }^{18}$ Badan Pengembangan dan Pembinaan Bahasa, Padanan Istilah Online, http://badanbahasa.kemdikbud.go.id/lamanba hasa/content/padanan-istilah-online-dan-ofline diakses pada tgl 18 Nov 2020 pukul 21.29 WITA. ${ }^{19}$ Adieb Lazwar Irkhami, "Jual Beli Account Game Online Mobile Legend Perspektif Sayyid Sabiq dan Hukum Positif”, Skripsi, Fak. Syariah, UIN Maulana Malik Ibrahim, Malang, 2019.
}

fighter, mage, dan assassin. Pada umumnya setiap hero memiliki satu skill pasif dan tiga skill aktif, kecuali "Zhask" yang mempunyai empat skill aktif. ${ }^{20}$

Saat mulai permainan, level hero akan dimulai dari level 1 dan dapat terus bertambah hingga maksimal level 5. ${ }^{21}$ Namun seiring berjalannya waktu, peringkat tinggi yang telah dicapai dapat dicapai dapat menghasilkan nilai ekonomis dengan cara menjual account yang dimilikinya kepada sesama pemain. Ada beberapa mekanisme yang dapat dilakukan oleh gamer untuk melakukan transaksi jual beli, antara lain:

1. Transaksi tidak langsung : pemain menjual lewat jejaring sosial media. Dalam praktiknya yang melakukan metode tersebut adalah customer (pembeli) yang tidak dengan wilayah yang sama dengan penjual. Cara ini dilakukan dengan mempomosikan account yang dimilikinya lewat berbagai sosial media yang ada seperti facebook, instagram, twitter dan lain-lain. Nantinya penjual akan menscreenshoot tingkatan level yang dimilikinya sehingga calon pembeli tertarik untuk membelinya, penjual tidak lupa mencantumkan kontak person yang dimilikinya agar nantinya calon pembeli menghubunginya secara langsung. Jual beli yang dilakukan oleh penjual dan pembeli ini secara online. Untuk penentuan harga ditetapkan melalui chatingan. Chatingan inilah yang dapat disebut sebagai akad jual beli yang dilakukan pemain satu dengan

\footnotetext{
${ }^{20}$ Ibid, 49.

${ }^{21} \mathrm{http}: / /$ www.mobilelegends.com/ diakses pada 17 juni 2021 pukul 22.40 WITA.
} 
Jurnal Ilmu Ekonomi dan Bisnis Islam - JIEBI

Vol. 3 No. 1 Tahun 2021

pemain lainnya melalui sosial media, baik itu percakapan melalui facbook, instagram, atau lainnya. Jika sudah terjadi kesepakatan, maka pihak pembeli akan mentransfer uang kepada si penjual lalu si penjual akan mengirim alamat account dan password game Mobile Legends.

2. Transaksi langsung : Penjual dan pembeli bertemu secara langsung. Dalam proses inilah penentuan harga dapat dilakukan dalam satu majlis dan tidak ada halangan untuk terjadinya kejahatan seperti penipuan yang biasanya terjadi. Cara ini terjadi apabila penjual dan pembeli tinggal dalam satu wilawah yang sama atau disebut dengan sistem COD. ${ }^{22}$

\section{METHODOLOGY}

Dalam penulisan karya ilmiah ini, penulis menggunakan metode pendekatan penelitian deskripsi kualitatif, 23 yaitu memaparkan aspekaspek yang menjadi sasaran penelitian penulis. Pendekatan yang dimaksud yaitu suatu penelitian yang berusaha untuk menuturkan pemecahan masalah yang ada sekarang berdasarkan datadata, sehingga penulis dapat menemukan kepastian dan keaslian data untuk diuraikan sebagai hasil penelitian yang akurat. ${ }^{24}$ Penelitian yang bersifat

\footnotetext{
${ }^{22}$ Adieb Lazwar Irkhami, "Jual Beli Account Game Online Mobile Legend Perspektif Sayyid Sabiq dan Hukum Positif”, Skripsi, Fak. Syariah, UIN Maulana Malik Ibrahim, Malang, 2019.

23 Nurdin, N. (2018). Institutional Arrangements in E-Government Implementation and Use: A Case Study From Indonesian Local Government. International Journal of Electronic Government Research (IJEGR), 14(2), 44-63. doi: 10.4018/ijegr.2018040104

${ }^{24}$ Evita, E., Syahid, A., \& Nurdin, N. (2019). Understanding Students' Learning
}

deskriptif menurut Suharsimi Arikunto "lebih tetap apabila menggunakan pendekatan kualitatif'.25, 26

Adapun yang menjadi objek atau sasaran lokasi penelitian adalah kumunitas pelaku game online Mobile Legend di kota. Ini menunjukan bawah objek penelitian di anggap sangat representatif terhadap judul penelitian yang diangkat penulis, karena disamping objek dianggap tepat, juga memberikan nuansa baru bagi penelitian dalam menambang pengalaman penelitian, khususnya aktifitas jual beli akun geme online dalam padangan Islam.

Data dikumpul melalui observasi, wawancara mendalam, dan dari berbagai dokumen yang ada. ${ }^{27}$ Dalam wawancara peneliti melakukan wawancara langsung dengan masyarakat yang dapat memberikan data yang menyakut masalah atau objek penelitian.

Outcomes Differences Through the Application of the Market Place Activity Type of Cooperative Learning Model and the Application of Conventional Learning Models International Journal of Contemporary Islamic Education, 1(1), 6785.

${ }^{25}$ Suharsimi Arikunto, Prosedur Penelitian Ilmiah, Suatu Pendekatan Praktek,Ed. II, (Cet. IX ; Jakarta : Rineka Cipta, 1993)h 209;

26 Nurdin, N., Stockdale, R., \& Scheepers, H. (2014b, 6-9 Jan. 2014). The Role of Social Actors in the Sustainability of EGovernment Implementation and Use: Experience from Indonesian Regencies. System Sciences (HICSS), 2014 47th Hawaii International Conference on System Science,

27 Nurdin, N., Stockdale, R., \& Scheepers, H. (2014). Coordination and Cooperation in E-Government: An Indonesian Local E-Government Case The Electronic Journal of Information Systems in developing Countries, 61(3), 1-21. 
Jurnal Ilmu Ekonomi dan Bisnis Islam - JIEBI

Vol. 3 No. 1 Tahun 2021

\section{HASIL DAN PEMBAHASAN}

\subsection{Sejarah Terbentuknya Community Hero (CH) Indonesia}

Community Hero adalah program resmi dari MLBB, dimana setiap Community Hero bisa mengadakan gathering, mini tournament,hingga tournament resmi dan mendapatkan dukungan langsung dari MLBB. ${ }^{28}$ Community Hero juga sebagai pengembang dari game Mobile Legends Indonesia. Adapun Community Hero bertugas membuat turnamen Mobile Legends untuk komunitasnya agar bisa hidup dan berkembang. ${ }^{29}$

Community Hero memiliki tanggung jawab sebagai berikut:

1) Menjadi representative Mobile Legends: Bang Bang ditiap kota

2) Membangun komunitas Mobile Legends: Bang Bang di berbagai kota

3) Menjalankan aktivitas komunitas Mobile Legends: Bang Bang

Adapun persyaratan untuk bergabung komunitas ini adalah sebagai berikut:

1) Mendaftar sesuai kota yang di tinggali, bukan kota lahir.

2) Kandidat harus memiliki KTP (minimum 17 tahun)

3) Harus menguasai bahasa Indonesia dan bahasa Inggris

4) Menguasai bahasa Mandarin akan menjadi kelebihan

5) Setidaknya mencapai Rank "Legend" di Mobile Legends: Bang Bang

28

https://m.facebook.com/story_fbid=18080561660128

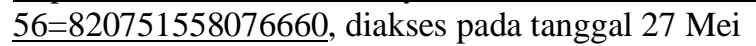
2021 pukul 21.32 WITA.

${ }^{29}$ https://youtu.be/C8Xs3WVXMCw, diakses pada tanggal 27 Mei 2021 pukul 21.41 WITA
1) Memiliki kemampuan berkomunikasi yang baik (tertulis dan verbal)

2) Memiliki pengalaman menjalankan $c l u b /$ komunitas akan menjadi kelebihan. ${ }^{30}$

\subsection{Community Hero di Berbagai Kota}

Saat ini Community Hero Indonesia masih beralamatkan di website, tidak ada secretariat atau semacamnya. Website dari Community Hero Indonesia bisa diakses melalui https://indoch.mobilelegends.com/.

Untuk ditiap daerah hampir seluruh Indonesia sudah memiliki komunitas ini dan memiliki nama masing-masing. ${ }^{31}$

Kegiatan dari komunitas game online ini ialah:

1) Mengadakan ghatering atau pertemuan

2) Merekrut anggota baru untuk dijadikan pengurus

3) Merekrut anggota komunitas baru di tiap daerah

4) Mengadakan tournament atau perlombaan

Pencapaian Community Hero adalah:

1) Terbentuknya team hebat e-sport Indonesia untuk Mobile Legends: Bang Bang yaitu Evos, dimana team ini sering mengikuti tournament berkanca Internasional. Di tahun 2018 berhasil meraih juara pertama dari 8 team diacara Internasional ProDotA Cup Southeast Asia, dan membawa pulang hadiah sebesar US $\$ 1,500$ jika

\section{${ }^{30}$ https://games}

.grid.id/amp/151676560/ikutan-mobile-legendsleader-community-kero-kuy-begini-caranya, diakses pada tanggal 27 Mei 2021 pukul 22.21 WITA

${ }^{31}$ https://indoch.mobilelegends.com/, diakses pada 28 Mei 2021 pukul 20.55 WITA 
Jurnal Ilmu Ekonomi dan Bisnis Islam - JIEBI

Vol. 3 No. 1 Tahun 2021

dirupiahkan mencapai sekitar Rp.22.500.000

2) Tahun 2019 berhasil membawa pulang trofi juara 1 World Championship yang merupakan ajang perlombaan tingkat dunia. ${ }^{32}$

\subsection{Profil Mobile Legends Community Hero} (MLCH) Kota Palu

Awal terbentuknya Mobile Legends Community Hero (MLCH) Palu adalah dengan sering mengikuti tournament yang diadakan oleh Community Hero Indonesia. Bukan hanya itu, para pendiri MLCH Palu juga sering ikut ghatering yang diadakan Community Hero Indonesia maupun $\mathrm{MLCH}$ antar daerah. Berdirinya komunitas ini dimulai pada tanggal 13 Janurai 2018.

Adapun tugas dari Mobile Legends Community Hero Palu antara lain:

1) Mengadakan ghatering antar anggota komunitas

2) Merekrut anggota baru (khusus 17 tahun keatas)

3) Sebagai wadah push rank (menaikkan level akun)

4) Mengadakan tournament antar anggota

5) Juga sebagai wadah transaksi jual beli akun, dan diamond. ${ }^{33}$

a. Community Hero di Kota Palu

1) Palu Freedom Of Community

2) Instinct Organizer

3) Alterion Organizer

4) Pioners Organizer

5) Mobile Legends Community Hero Palu. ${ }^{34}$

32 https://www.gametweeps.com/turnamenmlbb/prestasi-evos-mobile-legend-di-dunia-esports/, diakses pada tanggal 28 Mei 2021

${ }^{33}$ Wawancara bersama Moh Ridwan, tanggal 18 November 2020, di Jl Dewi Sartika
4.4 Mekanisme transaksi Jual Beli Account

Game Online Mobile Legends

Game merupakan permainan yang sering dilakukan oleh beberapa orang untuk memenuhi kebutuhan hidupnya sebagai sarana hiburan. Game online kini menjadi primadona dimata para gamers di tanah air.orang dapat mengisi waktu luang dengan bermain game dan berhubungan dengan orang-orang lain didalam game melalui chating yang terdapat pada game online. Ditambah lagi dengan tampilan yang bagus, fitur lengkap dan cara permainan game yang menarik.

Dalam prakteknya, jual beli account game online sudah merupakan hal yang biasa dilakukan oleh para pemain game online yang memiliki lebih dari satu account game atau mereka yang sudah bosan memainkan game Mobile Legends atau lebih dikenal dengan istilah mereka yang pensiun dari bermain game Mobile Legends.

Penjualan account game online Mobile Legends ini sama halnya dengan penjualan barang-barang lain yang dijual melalui dunia maya, atau market place yang ada. Bukan hanya transaksi online, penjualan account game Mobile Legends bisa dengan bertemu langsung atau COD.

Dalam praktek jual beli account game online Mobile Legends di kota Palu melalui komunitas yang bernama Mobile Legends Community Hero (MLCH) Palu melibatkan beberapa pihak didalam grup, dimana didalam komunitas tersebut terdapat grup

${ }^{34}$ https://indoch.mobilelegends.com/ diakses pada tanggal 28 Mei 2021 pikul 22.13 WITA

e-ISSN: 2686-6633 
Jurnal Ilmu Ekonomi dan Bisnis Islam - JIEBI

Vol. 3 No. 1 Tahun 2021

whatsapp yang menjadi media transaksi jual beli account Mobile Legends.

Kemudian objek dalam jual beli account game online Mobile Legends di kota Palu yaitu account dari game tersebut, yang terdapat id dan password dari account game online yang akan diberikan penjual kepada pembeli setelah permbayaran dilakukan.

Adapun salah satu penjual account game online Mobile Legends yang peneliti wawancarai pada tanggal 25 April 2021 bernama Rahmat A Sabri. Ia sudah bermain game online Mobile Legends sekitar satu tahun yang lalu. Dia mengatakan bahwa niatnya untuk menjual accountnya ingin menutup account yang dimilikinya. Harga yang ditentukan olehnya untuk account yang dijualnya sebesar Rp. 50.000, dengan modal Rp. 75.000/bulan yang merupakan dana untuk membeli kuota. Dalam transaksi ini, tidak terdapat keuntungan sama sekali. Kaena niat jualnya hanya untuk menutup account bukan untuk berbisnis.

Adapun transaksinyayang terjadi adalah bertemu secara langsung (COD). Meknisme penjualan yang dilakukannya ialah menangkap layar keadaan account nya yang berupa level, skin, emblem, dan hero yang banyak, dan di posting pada sosial media seperti whatsapp,facebook, dan instagram. Dalam penjualan ini tidak terdapat kejahatan seperti penipuan dikarenakan transaksinya dilakukan secara bertemu langsung.

Selanjutnya peneliti wawancara dengan Zulkifli Ma'ruf pada tanggal 25 April 2021 yang merupakan penjual account game online Mobile Legends. Zulkifli masih terbilang baru dalam memainkan game Mobile Legends yaitu selama dua bulan. Dia mengatakan bahwa niatnya menjual account game online Mobile Legends yang dimilikinya karena ingin berhenti bermain game online. Menurutnya spesifikasi account yang siap dijual adalah account yang memiliki hero, skin, emblem, dan diamond yang banyak. Zulkifli menjual account Mobile Legends nya dengan harga Rp. 50.000 dengan bermodalkan Rp. $75.000 /$ bulannya. Untuk mekanismenya sama dengan wawancara sebelumnya. Dalam transaksinya tidak memiliki keuntungan, dikarenakan niatnya menjual bukan untuk berbisnis.

Peneliti juga wawancara dengan Kevin pada tanggal 29 April 2021 yang merupakan penjual account game online Mobile Legends. Dia termotivasi menjual account game Online Mobile Legends dengan melihat kemampuannya serta banyaknya gamer yang mencari account yang dijual. Sehingga dia menjalankan bisnis dalam game online Mobile Legends. Bukan hanya account Mobile Legends yang dijual, melainkan juga diamond. Dia mengatakan penjualan account Mobile Legends harga paling murah Rp.3.000.000 dan penjualan tertinggi pernah mencapai Rp.9.500.000. Modal yang dikeluarkannya sebesar Rp.10.000.000/tiga bulan.

Modal ini digunakan untuk membeli hero, skin, dan diamond yang banyak. Untuk pendapatan per bulannya khusus penjualan account berkisar Rp.8.000.000. mekanisme yang digunakan dalam transaksinya berupa bertemu langsung (COD) atau secara online. Untuk menjual account biasanya dia melakukan promosi di berbagai sosial media, dan melakukan perjanjian untuk tempat bertemu. Penjualan online nya dia biasa menggunakan market place yang beralamatkan itemku.com. 
Jurnal Ilmu Ekonomi dan Bisnis Islam - JIEBI

Vol. 3 No. 1 Tahun 2021

Mekanisme dalam itemku.com pertama melakukan login pada web tersebut, lalu memilih kategori game yang ingin dijual serta memasukkan id dan password account yang dijual, kedua memilih account pada kolom kategori item yang dijual, selanjutnya memasukkan fotofoto hasil tangkap layar pada kolom yang disediakan, dan kemudian memasukkan harga penjualan. Penjualan terjadi secara otomatis dari market place tersebut, sehingga Kevin sisa menunggu dana yang masuk ke dompet digitalnya. Dalam transaksinya dia mengatakan tiada terjadi penipuan atau tindak kejahatan lainnya, karena transaksi yang dilakukan terbilang aman.

Selanjutnya peneliti melakukan wawancara dengan Fani Rahmasari sebagai penjual pada tanggal 29 Mei 2021. Dia mengatakan bahwa awalnya dia belum melihat peluang bisnis dari game online Mobile Legends, kemudian dia melihat temannya menjual account dari game online yang berbeda. Karena dia gamer dari game online Mobile Legends, maka dia mulai melakukan bisnis penjualan account Mobile Legends. Untuk spesifikasi account yang siap dijual, sama dengan hasil wawancara sebelumnya. Harga account yang biasa dia jual adalah Rp. 500.000 dengan bermodalkan Rp. 75.000/bulan dan kemampuannya dalam bermain. Keutungan yang biasa didapatkan per bulan bersihnya Rp.925.000 dengan penjualan maksimal dua account . untuk mekanismenya, dia hanya menerima pembelian secaara langsung dan tidak menerima pembelian dari luar daerah. Karena takut mengalami kerugian yang tidak diinginkan untuk tatacaranya sama dengan hasil wawancara sebelumnya.
Peneliti juga melakukan wawancara dengan Rasdi sebagai penjual pada tanggal 29 Mei 2021. Dia menjual account Mobile Legends nya untuk berhenti bermain game online karena dia melihat account nya bisa untuk dijual, maka dia menjualnya. Dia mengatakan bahwa harga account yang dijual sebesar Rp. 150.000 dengan modal Rp. 75.000 untuk pembelian kuota internetnya. Transaksi yang terjadi adalah bertemu langsung (COD) dan mekanismenya mencari teman yang butuh account game online Mobile Legends agar langsung laku tanpa melakukan promosi di berbagai sosial media.

Selanjutnya peneliti melakukan wawancara bersama Asy'ari sebagai pembeli pada tanggal 26 April 2021. Motivasi dia membeli account adalah menyukai account yang sudah memiliki banyak hero, diamond, dan emblem tanpa harus menunggu lama. Sebelum membeli, dia merasakan susah, karena hero yang ingin dipakainya bermain belum ada di account yang dimilikinya, dan kinerja hero yang tersedia terbilang sangat lambat menyebabkan dia selalu kalah disetiap pertandingan. setelah dia membeli account dia lebih merasa senang, karena hero yang disukainya ada dalam daftar hero dan kinerja hero nya sangat cepat tanpa harus menunggu lama dan selalu menang dalam tiap pertandingan. harga account yang dibelinya sebesar Rp. 80.000 dengan mekanisme bertemu langsung (COD).

Peneliti melakukan wawancara dengan Apriyatno sebagai pembeli pada tanggal 8 Mei 2021. Niat dia membeli account game online Mobile Legends dengan melihat tawaran yang murah, dengan kualitas yang bagus (biasa yang jual sedang ingin berhenti bermain atau 
Jurnal Ilmu Ekonomi dan Bisnis Islam - JIEBI

Vol. 3 No. 1 Tahun 2021

butuh uang). Harga account yang dibelinya sebesar Rp. 50.000 dengan kualitas account yang bagus. Sebelum membeli, dia lebih menikmati proses dalam bermain, dari lambannya hero, sedikitnya diamond yang biasa membuatnya tidak senang dalam pertandingan atau merasa tidak seru. Setelah membeli account dia lebih merasa senang, karena pertandingan menjadi lebih seru. Meknisme pembeliannya pun dengan bertemu langsung (COD).

Selanjutnya peneliti melakukan wawancara dengan Muhammad Ansar pada tanggal 9 Mei 2021. Awalnya dia tidak ingin membeli account, namun terdapat temannya yang sedang butuh uang dan menjual account Mobile Legends yang dimilikinya. Account yang dijual oleh temannya pun memiliki kualitas bagus, yaitu sudah memiliki banyak hero dan skin. Sebelum Ansar membeli account temannya, dia merasa kesulitan karena susah memilih hero yang ingin dipakainya, dan setelah dia membeli account temannya, hero yang selalu ingin dia gunakan ada tersedia di daftar hero. Harga account yang dibelinya adalah sebesar Rp. 150.000. Tentunya dengan mekanisme bertemu langsung (COD).

Peneliti juga melakukan wawancara dengan Arul sebagai pembeli pada tanggal 9 Mei 2021. Motivasinya membeli account game online Mobile Legends adalah untuk persiapan tournament. Tentunya dia membeli account yang memiliki hero, diamond, skin, dan emblem yang banyak serta level yang sudah tinggi (dalam game Mobile Legends biasa disebut Mitic Glory). Sebelum membeli proses pengebangan account sangat lambat, sehingga ditakutkan tidak dapat mengikuti tournament sesuai dengan waktu yang ditentukan. Setelah membeli account dia merasa sangat puas, karena bisa langsung mendaftarkan diri untuk ikut tournament dengan memperlihatkan level account yang dibelinya. Harga account yang dibelinya pun dengan harga yang tinggi yaitu sebesar Rp. 2.000.000. dengan mekanisme bertemu langsung (COD).

Terakhir, peneliti melakukan wawancara dengan Irfan sebagai pembeli pada tanggal 9 Mei 2021. Dia sangat hobby bermain game online Mobile Legends sehingga dia sangat menyukai account yang begitu banyak itemnya. Sebelum membeli, dia mengatakan bahwa hero yang dimilikinya masih sangat sedikit serta skin yang terbatas. Sehingga tidak bebas untuk bermain. Sesudah membeli account dia merasa lebih enak, karena bebas memilih hero dan memakai skin yang diinginkannya. Harga account yang dibelinya sebesar Rp. 2.400.000. Dengan mekanisme yang sama dari wawancara sebelumnya yaitu bertemu langsung (COD).

Sumber data: wawancara anggota Mobile Legends Community Hero Palu

Data diatas merupakan hasil wawancara terhadap penjual dan pembeli acoount Mobile Legends. Terjadinya transaksi jual beli account game online mobile legends disebabkan adanya dorongan kuat dari masingmasing individu yang menggunakan game tersebut khusus penjual ada yang butuh uang, ada yang ingin berhenti bermain, dan ada yang menjadikan ladang bisnis. Untuk pembeli dorongannya untuk memiliki account game online Mobile Legends yang dijual ialah karena suka, ingin cepat menikmati fitur-fitur yang tidak dimiliki 
Jurnal Ilmu Ekonomi dan Bisnis Islam - JIEBI

Vol. 3 No. 1 Tahun 2021

saat membuat account baru, dan ada juga karena ingin mengikuti tournament. Kebanyakan transaksinya berlangsung secara Cash On Delivery (COD). Namun ada juga yang menggunakan market place sebagai transaksi yang dilakukan secara online (biasa disebut dengan salam). Berikut mekanisme dari masing-masing transaksi jual beli account game online mobile legends yaitu:

a. Transaksi Cash On Delivery (COD)

1) Tangkap layar atau screenshoot fiturfitur account game mobile legendsI yang ingin dijual

2) Posting diberbagai account sosial media yang digunakan dengan menggunakan tulisan promosi yang menarik

3) Jika ada yang menghubungi untuk membeli, maka langkah selanjutnya adalah melakukan pertemuan. Pertemuan ini bisa di rumah penjual atau pembeli, dan bisa juga ditempat lain.

4) Menunjukkan lagi semua fitur game untuk meyakinkan pembeli.

5) Jika semua sudah ditunjukkan, akad terjadi dengan memberikan user dan password terlebih dahulu.

6) Langkah akhir ialah pembayaran. Bisa dilakukan dengan tunai ataupun nontunai.

b. Transaksi Online

1) Tangkap layar atau screenshoot fiturfitur account game mobile legendsI yang ingin dijual

2) Posting diberbagai account sosial media, dan market place yang digunakan dengan menggunakan tulisan promosi yang menarik

3) Membalas chat jika ada pertanyaan.

4) Jika penjualan di sosial media, sebelum memberikan account pembeli harus mentransfer 50\% dari harganya, dan sisanya diberikan setelah pemberian account.

5) Terakhir, jika penjualan di market place Itemku.com penjual mengiuti prosedur yang ada dalam market place tersebut dan cukup menunggu pembayaran dari pembeli.

\subsection{Perspektif Ekonomi Islam Terhadap Transaksi Jual Beli Account Game Online}

Berdasarkan penelitian yang telah penulis lakukan pada penjual dan pembeli account game online Mobile Legends di kota Palu pada sebuah komunitas yang bernama Mobile Legends Community Hero Palu, maka penulis akan menguraikan hasil penelitian tersebut menurut perspektif ekonomi Islam.

Sebagaimana diketahui, muamalah ialah semua hukum syariat yang bersangkutan dengan urusan duniawi, dengan memandang kelanjutan hidup seseorang. Seperti jual beli, tukarmenukar, pinjam-meminjam, berimemberi, dan lain-lainnya. ${ }^{35}$ dalam penelitian ini muamalah yang terjadi adalah jual beli.

Jual beli merupakan perbuatan kebajikan yang telah disyariatkan dalam Islam, hukumnya boleh. Mengenai transaksi jual beli ini banyak disebut dalam Al-Qur'an, hadist, dan ijma' .

Ayat Al-Qur'an yang berkenaan dengan transaksi jual beli adalah sebagai berikut:

Q.S An-Nisa/4:29:

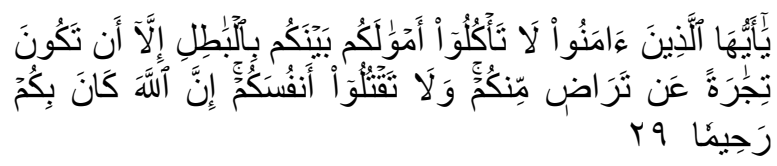

35 Ibnu Mas’ud, Edisi Lengkap Fiqh Mahzab Syafi'I, Bandung: Pustaka Setia, 2007, 19. 
Jurnal Ilmu Ekonomi dan Bisnis Islam - JIEBI

Vol. 3 No. 1 Tahun 2021

Terjemahnya:

wahai orang-orang yang beriman janganlah kamu saling memakan harta sesamaahmu dengan jalan yang batil (tidak benar), kecuali dalam perdagangan yang berlaku atas dasar suka sama suka diantara kamu. Dan janganlah kamu membunuh dirimu. Sungguh, Allah Maha Penyayang kepadamu. ${ }^{36}$

Pembahasan ayat tersebut ialah bentuk saling rela dalam transaksi ekonomi kontemporer ini banyak ditunjukkan dengan perilaku, perbuatan, atau saran kedua belah pihak, sehingga secara hukum Islam dinyatakan sah transaksinya. ${ }^{37}$

Hubungan ayat tersebut dalam penelitian ini ialah suka rela yang harus ada pada transaksi jual beli dalam bentuk apapun. Sehingga tidak terjadinya perilaku yang merugikan dalam transaksi jual beli khususnya pada akun game online Mobile Legends.

Kegiatan jual beli dalam Islam terdapat rukun dan syarat yang harus terpenuhi. Rukun yang di paparkan dalam beberapa mahzab adalah adanya orang yang berakad, atau penjual dan pembeli, ada sighat atau ijab Kabul, ada barang yang diperjual belikan, dan nilai tukar pengganti barang. Hal ini lebih dijelaskan pada bab dua. Dalam jual beli account game online Mobile Legends di kota Palu, khususnya pada anggota komunitas Mobile Legends Hero Community Palu sudah terlihat adanya

${ }^{36}$ Abu Fathan Al Baihaqi,Al-Fathan, (Jakarta; CV. Al Fatih Berkah Cipta, 2016), 83

${ }^{37}$ Ade Wahidin, Prinsip Saling Rela Dalam Transaksi Ekonomi Islam, (Bogor; UIN Syarif Hidayatullah), 133. pihak penjual dan pihak pembeli. Sighat atau ijab kabul dilakukan dengan adanya pertemuan yang dilakukan yang pastinya terjadi kesepakatan didalamnya.

Selanjutnya adanya barang yang diperjualbelikan juga terpenuhi dengan adanya account game online Mobile Legends sebagai objek jual belinya, uang yang diberi baik itu dalam bentuk transfer atau secara langsung kepada pihak penjual sebagai nilai tukar pengganti barang. Maka pelaksanaan jual beli game online Mobile Legends di kota Palu khususnya pada anggota komunitas Mobile Legends Community Hero Palu dari rukunnya sudah sesuai dengan rukun jual beli dalam Islam.

Mengenai syarat jual beli terkait dengan objek atau barang yang diperjualbelikan harus ada. Dalam penelitian ini objek barang yang diperjualelikan sudah terpenuhi berupa account game online Mobile Legends. Berikutnya syarat yang harus terpenuhi adalah objek transaksi berupa barang yang diperjualbelikan merupakan hak milik. Dalam transaksi jual beli account game online Mobile Legends ini kepemilikan bersifat mutlak bagi penjual, sehingga tidak ada masalah yang timbul terkait status kepemilikan pada account Mobile Legends yang telah dijual maupun dibeli.

Dalam transaksi jual beli, Allah SWT memberikan rambu-rambu agar berjalan sesuai dengan prinsip Islam yaitu menghindari perselisihan diantara kedua belah pihak, perbuatan yang dilarang. Diantara ketentuan tersebut yaitu anjuran agar setiap transaksi dalam muamalah dilakukan secara suka sama suka. 
Jurnal Ilmu Ekonomi dan Bisnis Islam - JIEBI

Vol. 3 No. 1 Tahun 2021

Selain atas suka sama suka, point penting adalah kepemilikan. Allah swt adalah pemilik mutlak atas alam dan segala isinya, dan apa yang terkandung didalamnya. Sedangkan manusia hanya diamanahkan oleh Allah sebagai khalifah-Nya di muka bumi ini. Islam memberikan hak kepada setiap individu untuk memiliki harta atau goods selama yang bersangkutan memperoleh benda tersebut secara sah dan melalui jalan yang halal. ${ }^{38}$

Berdasarkan perspektif ekonomi Islam, transaksi jual beli account game online Mobile Legends sudah sejalan dengan rukun dan syarat serta prinsip jual beli yang terkandung dalam ekonomi Islam, hal tersebut dilihat dari transaksi yang terjadi berdasarkan terpenuhinya rukun dan syarat jual beli, suka sama suka antara penjual dan pembeli. Serta keamanan dalam transaksi terjamin terlihat dengan kehati-hatian penjual dan pembeli account Mobile Legends, sehing tidak ada terdapat masalah dikemudian hari.

\section{KESIMPULAN DAN SARAN}

Berdasarkan hasil penemuan dalam penelitian ini, maka peneliti menyimpulkan bahwa terjadinya transaksi jual beli account game online mobile legends disebabkan adanya dorongan kuat dari masing-masing individu yang menggunakan game tersebut khusus penjual ada yang butuh uang, ada yang ingin berhenti bermain, dan ada yang menjadikan ladang bisnis. Untuk pembeli dorongannya untuk

${ }^{38}$ Nazaruddin A. Wahid, Paradigma Ekonomi Islam (Konsep Dasar,Pelaksanaan dan Kebijakan), (Banda Aceh: Searfiqh, 2013) 74. memiliki account game online Mobile Legends yang dijual ialah karena suka, ingin cepat menikmati fitur-fitur yang tidak dimiliki saat membuat account baru, dan ada juga karena ingin mengikuti tournament.

Kebanyakan transaksinya berlangsung secara Cash On market place sebagai transaksi yang dilakukan secara online (biasa disebut dengan salam). Berdasarkan perspektif ekonomi Islam, transaksi jual beli account game online Mobile Legends sudah sejalan dengan rukun dan syarat serta prinsip jual beli yang terkandung dalam ekonomi Islam, hal tersebut dilihat dari transaksi yang terjadi berdasarkan terpenuhinya rukun dan syarat jual beli, suka sama suka antara penjual dan pembeli. Serta keamanan dalam transaksi terjamin terlihat dengan kehati-hatian penjual dan pembeli account Mobile Legends, sehingg tidak ada terdapat masalah dikemudian hari.

\section{DAFTAR PUSTAKA}

al-Asqalany Al-Hafidh, Imam Ibnu Hajar, Bulughul Maram Min Adillatil Ahkaam, Hadist No.800, terj. Dani Hidayat, Tasikmalaya: Pustaka Al-Hidayat, 2008

AT, Andi Mappiare, Dasar-dasar Metodologi Riset Kualitatif Untuk Ilmu Sosial dan Profesi, Malang: Jenggala Pustaka Utama, 2009

Badan Pengembangan dan Pembinaan Bahasa, Padanan Istilah Online, http:/ / badanbahasa.kemdikbud .go.id/lamanbahasa/content/pa danan-istilah-online-dan-ofline 
Jurnal Ilmu Ekonomi dan Bisnis Islam - JIEBI

Vol. 3 No. 1 Tahun 2021

al Baihaqi, Abu Fathan, Al-Fathan, Jakarta; CV. Al Fatih Berkah Cipta, 2016

Pasaribu, Chairuman, Hukum Perjanjian dalam Islam, Jakarta: Sinar Grafika, 1996

Departemen Wakaf dan urusan Islam Kuwait, al-Mausu'ah Al-Fiqhiyyah Al-Kuwaityyah, Jilid; 2, Kuwait: At-Thab'ah Tsaniyah, $2006 \mathrm{M}$

EsportsID, MLBB Ceriakan Lagi Kota Palu, Pasca Gempa Tahun Lalu, https://esports.id/mobilelegen ds/news/2019/12/b181eaa49f5 92e16c772dcb718cd0f/mlbbceriakan-lagi-kota-palu-pascagempa-tahun-lalu,

Friatna, Ida, Konsep Laba Dalam Sistem Ekonomi Islam, Banda Aceh: Pena, 2012

https://m.mediaindonesia.com/humani ora/389057/kemenkominfo-89penduduk palu-gunakansmartphone

J Moelong, Lexy, Metodologi Penelitian Kualitatif, Bandung PT Remaja Rosdakarya, 2002

al-Juzburi Abdurrahman, Ibnu Iwadh, Figh Ala Mazahibul Arba'ah, Jilid; 5, Qahirah: Dar Ibnu Hitsam, 1960

M.Echols, Jhon, dan Hasan Sadily, Kamus Isnggris Indonesia, Jakarta: PT Gramedia Utama,2010

Margono S, Metode Penelitian Kualitatif, Cet; II, Jakarta: Rineka Cipta, 2000

Muhammad Muhammad, "Tantangan Dan Peluan Penerapan Kebijakan Mandatory Sertifikasi Halal (Studi Implementasi UU No. 33 Th.2014 dan Pp No.31 Th.2019)", Jurnal Fakultas Ekonomi dan Bisnis Islam, Institut Agama Islam
Negeri Palu, Vol. 2, No. 1, tahun 2020.

https://jurnaljiebi.org/index.ph $\mathrm{p} /$ jiebi/article/view/29/28

Natadipurba, Chandra, ekonomi Islam 101 edisi 2, Bandung: PT Mobidelta Indonesia, 2016

Noor, Juliansyah, Metodologi Penelitian, Jakarta:Kencana, 2011

Nurdin, N., Musyawarah, I., Nurfitriani, N., \& Jalil, A. (2020). Pengaruh Pelayanan Mobile Banking Terhadap Kepuasan Nasabah (Studi Pada Mahasiswa Perbankan Syariah IAIN Palu) Jurnal Ilmu Perbankan dan Keuangan Syariah, 2(2), 87-104.

Nurdin, N., Azizah, W. N., \& Rusli, R. (2020).

Pengaruh

Pengetahuan,Kemudahan dan Risiko Terhadap Minat Bertransaksi Menggunakan Finansial Technology (Fintech) Pada Mahasiswa Institut Agama Islam Negeri (IAIN) Palu Jurnal Ilmu Perbankan dan Keuangan Syariah, 2(2), 199-222.

Nurdin, N. (2018). Institutional Arrangements in E-Government Implementation and Use: A Case Study From Indonesian Local Government. International Journal of Electronic Government Research (IJEGR), 14(2), 44-63. doi: 10.4018/ijegr.2018040104

Nurdin, N., Stockdale, R., \& Scheepers, H. (2014b, 6-9 Jan. 2014). The Role of Social Actors in the Sustainability of E-Government Implementation and Use: Experience from Indonesian Regencies. System Sciences (HICSS), 2014 47th Hawaii 
Jurnal Ilmu Ekonomi dan Bisnis Islam - JIEBI

Vol. 3 No. 1 Tahun 2021

International Conference on System Science

Nurdin, N., Stockdale, R., \& Scheepers, H. (2014). Coordination and Cooperation in E-Government: An Indonesian Local EGovernment Case The Electronic Journal of Information Systems in developing Countries, 61(3), 1-21.

Nursyamsu, Moh. Idham, Ferdiawan, "Pelaksanaan Penimbangan Jual Beli Biji Coklat Dalam Tinjauan Ekonomi Islam : Studi Desa Bulili Kecamatan Nokilakaki Kabupaten Sigi", Jurnal Fakultas Ekonomi dan Bisnis Islam, Institut Agama Islam Negeri Palu, Vol. 2, No. 1, tahun

2020. https://jurnaljiebi.org/index.ph $\mathrm{p} /$ jiebi/article/view/34

Pasaribu Chairuman, Hukum Perjanjian dalam Islam, Jakarta: Sinar Grafika, 1996

Pelayananpublik.id, Pengertian Game Online, Sejarah, Hingga Jenisnya.https;/ / pelayananpubli k.id/2020/02/02/ pengertiangame-onlinesejarahhinggajenisnya/amp/\#aoh=160 57075192105\&referrer=https: / / www.google.com\&csi=1.

Pulsagram, Perkembangan Game Online di Indonesia, https:/ / www.pulsagram.com/b log/perkembangan-gameonline-di-indonesia/ diakses pada 18 Nov 2020 pukul 22.47 wita

Pusat Pengkajian dan Pengembangan Ekonomi Islam/P3EI,Ekonomi Islam, Cet; VI, Jakarta: Rajawali Pers, 2014
Rossa Gemala, Santri, "Pengaruh Game Online Terhadap Mahasiswa" http:/ / gemalasr.blogspot.co.id/ as-Sayyid, Sabiq, Figh as Sunnah, juz -3, Beirut: Dar al-Fikr, 1983

ash-Shawi, Shalah, dan Al-Mushlih Abdullah, Fikih Ekonomi Islam, cet. V, Jakarta: Darul Haq, 2015

Siddiq, Husein Shaharah, dan AdhDharil Muhammad, Transaksi dan Etika Bisnis Islam, Jakarta: Visi Insani Publishing, 2005

Suhendi, Hendi, Figh Muamalah, cet 9 Jakarta: Rajawali Pers,2014

Sugiyono, Metode Penelitian Kuantitatif Kualitatif dan RED, Cet; VIII, Bandung: Alfabeta, 2009

Sugiyono, Metode Penelitian Kuantitatif, Kualitatif dan Kombinasi Mixed Methods Cet; X, Bandung: Alfabeta, 2018

Sugiyono, Metode Penelitian Kualitatif, Cet; III, Bandung: Alfabeta, 2018

Suharsaputra, Uhar, Metode Penelitian Kualitatif, Kuantitatif Dan Tindakan, Cet; II, Bandung: PT Rafika Aditama, 2014

Surahmat Winarno, Dasar dan Teknik Riset, Bandung: Tarsito, 1998

Surat Keputusan Fatwa Dewan Syariah Nasional No: 05/DSNMUI/IV/2000 tentang Jual Beli Salam

Syarifuddin , Amir, Garis-garis Besar Fiqih, Bogor: Kencana, 2003.

Tungari, K., Nurdin, N., \& Kusumawati, D. (2016). Analisis Skill dan Ability Karakter pada Game Online Dota2 Esport. Jurnal Elektronik Sistem Informasi dan Komputer, 1(2), 17-35.

Umi Wahyuni MD, Siti Achiria, "Peran Trend dan Motif Hujrah Terhadap 
Jurnal Ilmu Ekonomi dan Bisnis Islam - JIEBI

Vol. 3 No. 1 Tahun 2021

Pembelian Busana Muslimah Di

Kota Palu", Jurnal Fakultas

Ekonomi dan Bisnis Islam,

Institut Agama Islam Negeri

Palu, Vo. 1, No. 2, tahun 2019. https://jurnaljiebi.org/index.ph

$\mathrm{p} /$ jiebi/article/view/9/8

Wahidin Ade, Prinsip Saling Rela Dalam

Transaksi Ekonomi Islam, Bogor;

UIN Syarif Hidayatullah

Wikipedia,

"Ekonomi"

https://id.m.wikipedia.org/wik

i/Ekonomi

Zulham, Hukum Perlindungan Konsumen, Jakarta: PT Kharisma Putra Utama, 2013 